\title{
Ny forskning fra Nasjonalt senter for selvmordsforskning og -forebygging (NSSF)
}

\section{Publikasjoner om behandlingskjede}

\author{
Mehlum, L., Jørgensen, T., Diep, L.M., \& Nrugham, L. (2010). \\ Is organizational change associated with increased rates of readmission to general hospital \\ in suicide attempters? A 10-year prospective catchment area study. \\ Archives of Suicide Research, 14(2), 173-183.
}

For å skape kontinuitet i behandlingen av selvmordsfors $\varnothing$ kere har mange sykehus og kommuner utviklet et gjensidig forpliktende samarbeid om oppfølgingen etter akuttbehandling på sykehuset. Organisasjonsmessige endringer kan imidlertid tenkes å virke negativt inn på slikt samarbeid. Aker Universitetssykehus (nå Oslo Universitetssykehus, Aker) har arbeidet med selvmordsfors $\varnothing$ kere etter behandlingskjedeprinsippet siden 1997, og det har blant annet lykkes å redusere tendensen til rask reinnleggelse i denne pasientgruppen. Da sykehuset i 2004 måtte endre sitt geografiske opptaksområde, skapte det store utfordringer for behandlingskjedetilbudet.

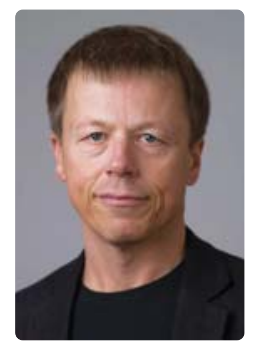

Lars Mehlum

I denne studien unders $\varnothing$ kte man hvorvidt forekomsten av reinnleggelse $\varnothing$ kte fra f $\varnothing \mathrm{r}$ til etter sektorendringen og hvilke faktorer som eventuelt var assosiert med endringer i reinnleggelsesraten. Sosiodemografiske og kliniske data ble innsamlet av klinikerne ved sykehuset fra i alt 911 pasienter som hadde vært innlagt i tidsrommet fra 1997 til 2007. Man fant en betydelig $\phi k t$ forekomst av reinnleggelse i tiden etter sektorendringen. Denne фkningen kunne ikke forklares av endringer i sosiodemografiske eller kliniske karakteristika ved pasientene. Man konkluderte med at selv om denne studien ikke kan si noe om kausale sammenhenger, kan den observerte assosiasjonen mellom sektorendringer og $\varnothing$ kte reinnleggelsesrater tyde på at behandlingskjedetiltak for selvmordsfors $\varnothing$ kere utskrevet fra sykehus kan være sårbare for slike endringer.

Rossow, I., Mehlum, L., Gjertsen, F., \& Møller, B. (2009).

Chain of care for patients with intentional self-harm. An effective strategy to reduce suicide rates? Suicide and Life-Threatening Behavior 2009; (39(6):14-22.

Er behandlingskjede for pasienter med selvmordsfors $\varnothing \mathrm{k}$ en effektiv strategi for å redusere selvmordsratene? Etablering av en behandlingskjede for pasienter med selvmordsfors $\varnothing \mathrm{k}$ står sentralt $\mathrm{i}$ handlingsplanen for forebygging av selvmord. En behandlingskjede innebærer at pasienten følges opp av en eller flere behandlingsinstanser. Forfatterne av denne studien har beregnet den potensielle effekten av behandlingskjede på selvmordsraten under ulike betingelser, og sammenliknet endringer i selvmordsrater mellom områder med og uten behandlingskjede. Beregningene av potensielle effekter viste at selv under urealistisk gunstige betingelser vil den forventete effekten være svært liten.

Sammenlikningene av observerte selvmordsrater over tid viste at det ikke var noen forskjeller i endringene mellom områder med og uten behandlingskjede. Studien gir derfor ingen belegg for at en slik individrettet risikostrategi er effektiv for å redusere selvmordsratene i befolkningen.

Mehlum, L., Mork, E., Reinholdt, N.P., Fadum, E.A., \& Rossow, I. (2010).

Quality of psychosocial care of suicide attempters at general hospitals in Norway -a longitudinal nationwide study. Archives of Suicide Research, 14(2), 146-157.

Mork, E., Mehlum, L., Fadum, E., \& Rossow, I. (2010).

Collaboration between general hospitals and community health services in the care of suicide attempters in Norway: a longitudinal study. Annals of General Psychiatry, 9, 26.

Oppfølging av pasienter behandlet i somatisk sykehus etter villet egenskade var et viktig satsningsområde i Handlingsplan mot selvmord i Norge. Behandlingskjedeprosjekter ble gjennomført ved ca. 1/3 av norske somatiske sykehus. To norske studier hadde som formål å identifisere indikatorer som predikerer høy kvalitet over tid i dette arbeidet. I 1999 og 2006 ble det gjennomført strukturerte intervju med nøkkelinformanter ved $87 \%$ av medisinske avdelinger med akuttmedisinsk funksjon i Norge. Mehlum og kolleger (Mehlum, Mork, Reinholdt, Fadum, \& Rossow, 2010) fant at sykehus som både hadde systematisk opplæring av personal og skriftlige rutiner for arbeidet med pasienter innlagt for villet egenskade hadde høyere kvalitet på rutinene 7 år senere. Implementering av et tidsbegrenset behandlingskjedeprogram på 1990-tallet var også assosiert med høyere nivå på kvalitetsindikatorer i 2006.

Den andre studien (Mork, Mehlum, Fadum, \& Rossow, 2010) hadde som mål å identifisere hvorvidt kvalitetsindikatorer ved sykehusene kunne predikere hvorvidt norske kommuner hadde en behandlingskjedestruktur i 2006. Strukturerte intervju med et stratifisert utvalg på 47 norske kommuner viste at 15 av 47 kommuner (32\%), hadde en behandlingskjedestruktur. Kommuner tilknyttet sykehus som i 1999 hadde samarbeidsavtale med oppfølgende instans og skriftlige rutiner med et system for kvalitetskontroll, hadde signifikant oftere behandlinskjede enn kommuner tilknyttet sykehus uten disse kvalitetsindikatorene.

Studiene antyder at rutinene for oppfølging etter villet egenskade ved norske sykehus og kommuner var markert under det som er anbefalt. Systematisk samarbeid mellom nivåene i helsetjenesten og gode kvalitetssikringsrutiner inkludert opplæring av personal kan være viktige elementer i å opprettholde behandlingskjedetiltak over tid. 